This PDF is a selection from an out-of-print volume from the National Bureau of Economic Research

Volume Title: When Public Sector Workers Unionize

Volume Author/Editor: Richard B. Freeman and Casey Ichniowski, eds.

Volume Publisher: University of Chicago Press

Volume ISBN: 0-226-26166-2

Volume URL: http://www.nber.org/books/free88-1

Publication Date: 1988

Chapter Title: Union/Nonunion Wage Gaps in the Public Sector

Chapter Author: H. Gregg Lewis

Chapter URL: http://www.nber.org/chapters/c7908

Chapter pages in book: (p. 169 - 194) 


\title{
Union/Nonunion Wage Gaps in the Public Sector
}

\author{
H. Gregg Lewis
}

This paper presents the results of a survey of micro, ordinary least squares, cross-section studies of the union/nonunion wage gap in the public sector with the aim of providing mean gap estimates for that sector that are more or less comparable to those for the economy as a whole. ${ }^{1}$ The survey covers seventy-five studies ${ }^{2}$ and deals with several estimation problems involved with interpreting those studies. ${ }^{3}$

\subsection{Conceptual Issues}

Suppose that the concept of union status for a worker at his job is the following dichotomy: if he is unionized, his wages and working conditions are negotiated for him by a union recognized by his employer and he is covered by the negotiated collective bargaining contract; otherwise, he is nonunion and none of these, not even representation by a union, is present. Furthermore, for the moment, I do not divide the unionized category into subcategories by type of union, whether the worker is a member of the union, and so on.

Hence, denote union status by a single dummy variable $U=1$ if unionized and zero otherwise. Let $W_{i}$ be the natural logarithm of the worker's wage where $i=u$ if $U=1$ and $i=n$ if $U=0$, and his "wage" is his hourly compensation including fringe benefit costs. Then the union/nonunion wage gap for the worker is $W_{u}-W_{n}$ and the mean gap for a group of workers is $\bar{W}_{u}-\bar{W}_{n}$, where $\bar{W}_{i}(i=u, n)$ denotes the mean of $W_{i}$ for the group. The estimation problem is obvious: for each worker only $W_{u}$ or $W_{n}$ is observed; the other must be estimated.

H. Gregg Lewis is Professor Emeritus, Duke University, and a research associate of the National Bureau of Economic Research. 
The most common method of estimation is to fit wage equations by ordinary least squares (OLS) to cross-section (CS) data for a sample of individual workers on their wages, union status, and variables controlling for some of the characteristics of workers and their jobs. Let the wage equation have the following form:

$$
W=a_{n}+\sum a_{n i} X_{i}+U\left[a_{u}-a_{n}+\sum\left(a_{u i}-a_{n i}\right) X_{i}\right]+e,
$$

where the $a$ 's are the estimated coefficients, the $X$ 's are control variables characterizing the worker (sex, race, age, schooling, etc.) and his job (industry, occupation, locality, etc.), and $e$ is the residual. I use the term micro/OLS/CS to describe such equations. Then an estimate of the mean union/nonunion wage gap $\bar{M}$ for the sample of workers is:

$$
\bar{M}=a_{u}-a_{n}+\Sigma\left(a_{t i}-a_{n i}\right) \bar{X}_{i}
$$

where $\bar{X}_{i}$ is the sample mean of $X_{i}$. (Of course, if the interactions $U X_{i}$ are all omitted in fitting (1), the mean wage gap estimate $\bar{M}$ is simply the coefficient $a_{w}-a_{n}$ of $U$ in the wage equation.)

This micro/OLS/CS wage gap estimate (2), however, may be seriously biased for any of the following reasons:

1. Important wage-explanatory variables that are correlated with the union status variable $U$ have been omitted in fitting (1). This is the union status selectivity problem which has been the subject of numerous empirical studies.

Public sector union/nonunion wage gap estimates are often fitted to data obtained by surveying establishments-hospitals, school districts, police and fire departments, and the like-rather than households. Establishment data tend to be more informative of employment or job characteristics than of the worker characteristics in which household surveys are rich, and often pertain to groups of workers (such as police) who are homogeneous by occupation and industry. It is by no means obvious to me that these differences between establishment and household data produce greater rather than smaller selectivity bias in establishment-based gap estimates than in those from household data. ${ }^{4}$ In any case, I will make no adjustment of public sector wage gap estimates for selectivity bias, whether the estimates are based on household or on establishment data.

2. The wage and union status variables may be inaccurately measured. Commonly, fringe benefit costs are omitted from the measured wage, and often weekly, monthly, or annual (instead of hourly) wage measures have been used. And sometimes the dependent wage variable is expressed in its natural arithmetic unit rather than in a logarithmic unit. Furthermore, even when union status is dichotomous, workers may be misclassified by union status. In addition, in some contexts, 
especially in the public sector, accurate description of union status may require more than the two categories, union and nonunion.

Specifically, in the private sector, with few exceptions, unionized status $(U=1)$ implies that a worker is represented by a union, the union is recognized by the employer as the exclusive bargaining agent for the employee's bargaining unit, the employer is obliged to bargain with the union agent, and the outcome of bargaining is a written collective bargaining agreement or contract. ${ }^{5}$ In contrast, in the public sector, unionized status, as I use the term, need not imply the entire complement of union representation, union recognition, bargaining, and a collective bargaining contract. A worker may be represented by a union that the employer has not recognized, will not bargain with, and with whom he will not enter into a contract. Or the employer may send an underling to "meet and confer" with the union representatives. Or he may agree to bargain with the union, but not to enter into a written contract. Or he may recognize the union as exclusive bargaining agent, bargain with it, and enter into a written contract. Thus much more for the public than for the private sector, union status cannot be accurately described by a single union status dummy variable based on union membership or contract coverage.

For example, Ehrenberg, in his study of fire fighters (1973), distinguished between three categories of city fire departments: those with written contracts with the fire fighter's union (IAFF), those in which an IAFF local was present but did not have a contract, and all other cities. Let $U_{1}=1$ if an IAFF local was present (with or without a contract) and zero otherwise; $U_{2}=1$ if the IAFF local had a contract and zero otherwise; and write the fitted micro/OLS/CS wage equation as

$$
W=a+\sum a_{i} x_{i}+M_{1} U_{1}+\left(M_{2}-M_{1}\right) U_{2} .
$$

Then $M_{1}$ estimates the union/nonunion wage gap for cities in which the IAFF local was present but had no contract, and $M_{2}$ estimates the corresponding gap for IAFF cities with a contract. Furthermore the estimated mean gap $\bar{M}$ for both categories of IAFF cities is:

$$
\bar{M}=M_{1}+\frac{\bar{U}_{2}}{\bar{U}_{1}}\left(M_{2}-M_{1}\right),
$$

where $\bar{U}_{i}(i=1,2)$ is the mean of $U_{i}$ over the city observations.

3. The sample may not be a random (self-weighting) sample of the population it purports to represent. For example, in two of the data sets (National Longitudinal Surveys [NLS] of older men and the Panel Study of Income Dynamics [PSID] sets that include the so-called "nonrandom half") commonly used in wage gap estimation, the sampling design resulted in heavy over-representation of black workers. This 
would not matter if the observations were properly weighted or if wage gap estimates were made separately by race and then averaged with proper weights. But if the wage gap for black workers exceeds that for white workers, as it appears to in these data, and if no steps are taken to overcome the oversampling of blacks, the wage gap estimates for the two races combined will tend to be biased upward. In Lewis (1986, 159-61), I made the following adjustment for such bias in the pertinent all-sectors wage gap estimates:

$$
\text { Adjustment }=0.21\left(\bar{M}_{B}-\bar{M}_{W}\right),
$$

where $\bar{M}_{B}-\bar{M}_{W}$ was my estimate of the excess of the mean wage gap for black workers over that for white workers. For the NLS data I put $\bar{M}_{B}-\bar{M}_{W}$ at almost 0.12 and for the PSID data at about 0.06 . Thus the resulting adjustments were -0.024 for the NLS-based estimates and -0.012 for the PSID. Unfortunately, we have very little evidence on which to base corresponding adjustments to wage gap estimates for public sector workers: Shapiro's study (1978) using NLS data and studies by Moore and Raisian $(1981 ; 1982 ; 1983)$ using PSID data. However, these studies show much smaller values of $\bar{M}_{B}-\bar{M}_{W}$ for the public sector than for the private sector. Therefore, where appropriate, I will make the following adjustments for oversampling of blacks:

NLS data, all sectors: -0.02 ; public sector: zero

PSID data, all sectors: -0.01 ; public sector: zero

4. A common comment on union wage effect estimates is that they do not take into account spillover effects from unionized workers to nonunion workers. It is surely true that in the general equilibrium of the economy in the presence of unionism the wages of nonunion workers are affected by what happens in the unionized sector. In that sense there are spillovers from the unionized to the nonunion sector. In what respect do wage gap estimates fail to take these spillovers into account?

Imagine a U.S. economy differing from the actual one only in that antitrust laws have made unions powerless to affect wages. In this economy a worker paid a wage $W_{i}(i=u$ if $U=1, i=n$ if $U=0)$ in the actual economy would be paid a wage $V$. The wage gap for the worker is $M=W_{u}-W_{n}$. His pair of union-induced wage gains, however, is $A_{i}=W_{i}-V$ where $i=u, n$. Of course, $M=A_{u}-A_{n}$. Let $\bar{M}, \bar{A}_{u}$, and $\bar{A}_{n}$ be the means of $M, A_{u}$, and $A_{n}$ for a group of workers. Then for this group $\bar{M}=\overline{A_{u}}-\overline{A_{n}}$ where $\overline{A_{n}}$ in general will not be zero because of spillovers from the unionized sector of the economy. Hence if $M$ is used as an estimate of the gain $\bar{A}_{u}$, the gap estimate $\bar{M}$ can be said to fail to take the spillovers $\overline{A_{n}}$ into account. ${ }^{6}$

Consider now a special class of spillover effects that I term parity effects. For example, a city government whose fire fighters (or police officers, teachers, nurses, etc.) are nonunion has a policy of paying 
them the "same" wages, conditional on some comparability criteria, as are paid to some "comparable" group of unionized workers in the same city or some other city. The reason for the parity policy may be fear that without it the fire fighters will become unionized. Parity effects stemming from such a policy are commonly termed threat effects. The reason for the policy, however, is not critical. What is critical is pursuit of wage parity between a group of nonunion workers and a "comparable" group of unionized workers.

Suppose that in a cross-section study of, say, city fire fighters, the cities practicing such wage parity for their nonunion fire fighters have been identified. Let $U_{p}=1$ for a parity city and zero otherwise. Then it is straightforward to make wage gap estimates that take parity effects into account, provided that there are some cities whose fire departments are classified as nonunion and nonparity. Return to equation (3). For present purposes modify it by adding $U_{p}$ as a righthand variable, suppressing $U_{2}$, and writing $U_{1}$ simply as $U$.

$$
W=d+\sum d_{i} X_{i}+P U_{p}+M_{a} U
$$

The coefficient $P$ of $U_{p}$, expected to be positive, estimates the parity effect-i.e., the wage gap between parity cities and other nonunion cities. Similarly, the coefficient $M_{a}$ of $U$ estimates the wage gap between union cities and nonunion, nonparity cities. Thus $M_{a}$ takes parity effects into account. The corresponding gap estimate, $M_{b}$, that does not take parity effects into account is $M_{b}=M_{a}-\bar{U}_{p} P /(1-\bar{U})$. Clearly, if $U_{p}=1-U, U_{p}$ and $U$ are perfectly negatively correlated and $P$ and $M_{a}$ cannot be estimated.

In a cross-section study of fire fighters (or police officers, teachers, etc.) covering a substantial number of cities in which the fire departments were nonunion, positive identification city by city of the parity cities would be tedious and expensive. Indeed, I know of no wage gap studies that have attempted such identification. Instead, students of the subject have used what they regarded as plausible proxies for $U_{p}$. I think that it is fair to say that the notion underlying all of these proxies is that parity is practiced if and only if the environment is favorable to collective bargaining by the reference group of workers, here fire fighters. Denote the criterion variable by $F$ where $F=1$ if the environment is judged to be favorable and zero otherwise. In the Zax study (1985) of city workers by department (fire, police, etc.), $F=1$ if and only if the city bargained with at least one union that was recognized by the city as the bargaining agent for some group of city workers. In the Freeman, Ichniowski, Lauer study (1985) of city police departments, $F=1$ if and only if state or local law permitted collective bargaining between the city and a union or unions representing its police officers. In numerous other studies, $F=1$ for the reference group if and only 
if the extent of unionism (fraction unionized) $y$ of some comparison group of workers exceeded some threshold level $y_{T} \geq 0$.

For any specification of $F$, the city fire departments may be divided into four mutually exclusive and exhaustive classes as follows:

Parity: $U_{p}=1$ if and only if $U=0, F \cdot=1$;

Weak union: $U_{w}=1$ if and only if $U=1, F=0$;

Strong union: $U_{s}=1$ if and only if $U=F=1$;

Nonunion, nonparity: if and only if $U=F=0$.

(The weak union class may be empty, $\bar{U}_{w}=0$. In that event, $U_{s}=U$. But none of the other three classes may be empty; if any of the three is an empty class, $P$ and $M_{a}$ cannot be estimated from the data.) Then the parity effect and the union/nonunion wage gap $M_{a}$ that takes the parity effect into account may be estimated from either of the following fitted equations:

$$
\begin{gathered}
W=d+\Sigma d_{i} X_{i}+P U_{p}+M_{w} U_{w}+M_{s} U_{s}, \\
W=d+\Sigma d_{i} X_{i}+P F+M_{w} U+\left(M_{s}-M_{w}-P\right) I,
\end{gathered}
$$

where $I \equiv U F$ is the interaction of $U$ and $F$. In these equations $P$ is the parity effect estimate and $M_{w}$ (weak union) and $M_{s}$ (strong union) are union/nonunion wage gap estimates that take parity into account. $M_{a} \equiv\left(\bar{U}_{w} M_{w}+\bar{U}_{s} M_{s}\right) / \bar{U}$ is the mean gap estimate taking account of parity and $M_{b}=M_{a}-\bar{U}_{p} P /(1-\bar{U})$ is the corresponding estimate that does not take account of parity. If the weak union class is empty $\left(\bar{U}_{w}=0\right)$, then (5a) and (5b) become:

$$
\begin{gathered}
W=d+\Sigma d_{i} X_{i}+P U_{p}+M_{a} U, \\
W=d+\Sigma d_{i} X_{i}+P F+\left(M_{a}-P\right) U .
\end{gathered}
$$

Suppose that the weak union class is not empty and that the fitted wage equation is like (5b) except that the interaction variable $I \equiv U F$ is omitted. Let $b_{U}$ and $b_{F}$ be the estimated coefficients of $U$ and $F$ in such an equation. Then $b_{F}$ is a biased estimate of $P$ and $b_{U}$ is a biased estimate of $M_{a}-P$. In order to estimate the size of the biases by the omitted variable theorem I assume that $0 \leq M_{w} \leq M_{s}$ and I ignore correlations of $U, F$, and $I$ with the control $X$ 's. Then

$$
\begin{gathered}
b_{F}-\frac{b_{U} B_{I F}}{B_{I U}} \leq P \leq \frac{b_{F}}{1-B_{I F}}, \\
\frac{\bar{U}_{s}}{\bar{U}}\left[b_{F}+\frac{b_{U}\left(1-B_{I F}\right)}{B_{I U}}\right] \leq M_{a} \leq b_{U}+\frac{b_{F} B_{I U}}{1-B_{I F}}, \\
D B_{I F}=\bar{U}_{w} \bar{U}_{s}(1-\bar{U}) ; D B_{I U}=\bar{U}_{p} \bar{U}_{s}(1-\bar{F}), \text { where } \\
D=\bar{U} \bar{F}\left(1-\bar{U}_{p}-\bar{U}_{w}\right)-\left(\bar{U}_{s}\right)^{2}>0 ; M_{b}=M_{a}-\frac{\bar{U}_{p} P}{1-\bar{U}},
\end{gathered}
$$


where the overhead bars denote means and $\bar{U}=\bar{U}_{w^{\prime}}+\bar{U}_{s}$ and $\bar{F}=\bar{U}_{p}+\bar{U}_{s}$. As $\bar{U}_{n} / \bar{U}=\left(\bar{U}-\bar{U}_{s}\right) / \bar{U}$ goes to zero, $B_{I F}$ goes to zero and $B_{I U}$ to unity.

In going from equation (3) to equations (5a), (5b), (6a) and (6b) I suppressed the distinction in equation (3) between union cities with a written collective bargaining contract $\left(U_{2}=1\right.$ in equation [3]) and other union cities $\left(U_{1}-U_{2}=1\right.$ in equation [3]). In what follows in this paragraph I maintain rather than suppress this distinction. Write $U_{0}$ for $U_{1}-U_{2}$ and assume for simplicity in the analysis that $F=1$ whenever $U_{0}$ or $U_{1}$ is unity. Then (6b) with the following modification is applicable:

$$
\begin{aligned}
W & =d+\Sigma d_{i} X_{i}+P F+\left(M_{0}-P\right) U_{0}+\left(M_{2}-P\right) U_{2}, \\
M_{a} & =\left(\bar{U}_{0} M_{0}+\bar{U}_{2} M_{2}\right) / \bar{U} ; \bar{U}=\bar{U}_{0}+\bar{U}_{2},
\end{aligned}
$$

where $M_{0}, M_{2}$, and $M_{a}$ are union/nonunion wage gap estimates that take account of parity. Suppose, however, that in fitting (8) the variable $U_{0}$ is omitted. Denote the resulting coefficients of $F$ and $U_{2}$ by $b_{F}$ and $b_{2}$, respectively. It seems reasonable to assume that $P<M_{0}<M_{2}$. Then if correlations of $U_{0}, U_{2}$, and $F$ with the $X$ 's are ignored, it follows from the omitted variable theorem that $M_{2}=b_{F}+b_{2}$ and $b_{F}-\bar{U}_{0} b_{2}$ ' $\bar{U}_{p}<P<b_{F}$. That is, the coefficient $b_{F}$ of $F$ in the fitted equation is an overestimate of the parity effect. This is to be expected (if $M_{0}>P$ ) since the effect of omitting $U_{0}$ is to classify union cities without a written contract as parity cities. With the above reasoning, however, the estimate $M_{2}=b_{F}+b_{2}$ is not biased and takes parity into account. I presume that $M_{a}<b_{F}+b_{2}$.

Return now to equation (6b) and assume that in fitting this equation $F$, but not $U$ or $I=U F$, has been omitted. Then it is impossible to derive an estimate of the parity effect from the fitted equation. However, $M_{b}=b_{U}+\bar{U}_{s} b_{l} / \bar{U}$ where $b_{U}$ and $b_{l}$ are the coefficients of $U$ and $I$, respectively.

I mentioned earlier that in some studies $F=1$ if and only if the extent of unionism $y$ of some specified comparison group of workers exceeded a threshold level $y_{T} \geq 0$. To simplify what follows assume that $\bar{U}_{w}=0$ so that equation (5b) is applicable. In (5b) let $P$ and $M_{a}$ be linear functions of the chosen $y$-variable on $y>y_{T}: P=g+g_{y} y$; $M_{a}-P=h+h_{y} y$. Then (5b) becomes

$$
W=d+\Sigma d_{i} X_{i}+g F+g_{y} F y+h U+h_{y} U y .
$$

A substantial number of studies reported wage equations resembling (9) in that they included $U$, a $y$-variable, and sometimes its interaction $U y$ with union status $U$, but differing from (9) in omitting $F$ and $F y$. According to (9) the expected wage in a nonunion, nonparity city is $W_{n}=d+\sum d_{i} X_{i}$, in a parity city it is $W_{p}=W_{n}+g+g_{y} y$, and in a 
union city it is $W_{u}=W_{p}+h+h_{y} y$. But suppose that in (9) $F$ is set equal to unity so that the equation reads

$$
W=(d+g)+\sum d_{i} X_{i}+g_{y} y+h U+h_{y} U y .
$$

Then because the coefficient $g$ of $F$ in (9) disappears into the intercept term $d+g$ in (10), $W_{n}, W_{p}$, and, therefore, $P=W_{p}-W_{n}$ and $M_{a}=P+h+h_{y} y$ cannot be estimated from (10). In effect (10) implicitly assumes that $F=1$, i.e., there are no nonunion, nonparity cities. But then, as I remarked early on in this section, parity effects cannot be estimated.

The Zax study (1985), is the only study, to the best of my knowledge, of either private sector or public sector union/nonunion wage gaps in which the wage equations were modeled so as to permit straightforward estimation of the parity effects. His study covered a nationwide sample of 889 cities in the years 1975, 1977, and 1979 and, within each city and year, four departments (or department groups): police, fire, sanitation, and other noneducational groups. The city*year*department observations were pooled and the wage equations included dummy variables for year and department.

Within each city and year the four departments were classified by union status as follows:

$U O=1$ if and only if some workers in the department were union members, but the union was not recognized by the city for bargaining purposes.

$U R=1$ if and only if some workers in the department were union members and the union was legally recognized by the city for bargaining purposes.

$N U=1$ if and only if $U 0=U R=0$.

In addition the cities in each year were classified into two categories (favorable or unfavorable to collective bargaining with its employees) by the dummy variable: $F=1$ if and only if the city has legally recognized at least one union as bargaining agent for some of its employees. Then in each year the city*department observations were divided into five mutually exclusive union status classes as follows:

Parity: $U_{p}=1$ if $U 0=U R=1-F=0$;

Weak union: $U_{w}=1$ if $F=1-U 0=0$;

Medium union: $U_{m}=1$ if $U 0=F=1$;

Strong union: $U_{s}=1$ if $U R=1$;

Nonunion, nonparity: if $U 0=U R=F=0$, the omitted base group in the wage equations.

In addition to the dummy variables for year (2), department (4), and union status (4), the fitted wage equation included region, city-size, income, alternative wage, and demographic variables. Two wage measures, the conventional hourly wage (HW) and hourly total compensation (HC) were used. 
The estimated coefficients (in logarithmic units) of the union status variables were:

$\begin{array}{llcc}\text { Line } & \text { Union Status } & \text { Dependent } & \text { Variable } \\ & & & \text { HW } \\ & & .032 & .048 \\ 1 & \text { Parity }\left(U_{p}\right) & .037 & .041 \\ 2 & \text { Weak union }\left(U_{w}\right) & .060 & .082 \\ 3 & \text { Medium union }\left(U_{m}\right) & .081 & .107 \\ 4 & \text { Strong union }\left(U_{s}\right) & .073 & .097 \\ 5 & \text { Mean, parity adjusted }\left(M_{a}\right) & .066 & .086\end{array}$

The wage gap estimates on lines $1-4$ take parity effects into account in the sense that the base of the wage comparisons is the nonunion, nonparity observation. The parity effect itself, on line 1, though small, is roughly as large as the "weak union" gap on line 2 . The parity adjusted mean $\left(M_{a}\right)$ is the weighted mean of the corresponding figures on lines 2-4. The parity unadjusted mean $\left(M_{b}\right)$ is the estimated (weighted) mean wage gap between the three unionized groups (weak, medium, and strong) and all nonunion observations including the parity observations. The excess of $M_{a}$ over $M_{b}$ is a quite modest 0.01 . This is the best estimate that $I$ have of the adjustment of public sector wage gap estimates to take parity effects into account.

\subsection{Survey of Broad Coverage Wage Gap Estimates}

In this section I summarize the wage gap estimates that I have drawn from micro/OLS/CS wage equations and related data reported in (or obtained from the authors of) studies with moderately broad to broad coverage of public sector workers. All of the wage equations were fitted to household survey data for individual workers.

Table 6.1 briefly describes these twenty-two studies. Column 2 identifies each study by author and date of publication; column 3 gives the source of the household survey data that were used; column 4 gives the year or years to which the wage gap estimates pertain; while column 5 is a short and somewhat incomplete description of the worker coverage of the wage gap estimates. (All of the studies exclude workers with missing data, the self-employed, and unpaid family workers. Most of them also exclude farm and private household workers.) In the nine studies listed on the first eleven lines of the table, the wage gap estimates for the public sector pertain to the whole of that sector as indicated by "All" in column 6 . In the remaining thirteen studies the public sector gap estimates pertain only to the parts of the public sector identified in column 6 . For example, the public sector gap estimates from Antos (1980), line 13, are for workers employed in the public 
(2)

(3)

(5)

(6)

(7)

(8)

(9)

(10)

\begin{tabular}{|c|c|c|c|c|c|c|c|c|c|}
\hline \multirow{2}{*}{$\begin{array}{l}\text { Line } \\
\text { No. }\end{array}$} & \multirow[b]{2}{*}{ Study } & \multirow{2}{*}{$\begin{array}{c}\text { Data } \\
\text { Source }\end{array}$} & \multirow[b]{2}{*}{ Year } & \multirow{2}{*}{$\begin{array}{c}\text { Worker } \\
\text { Coverage }\end{array}$} & \multirow{2}{*}{$\begin{array}{l}\text { Public } \\
\text { Sector }\end{array}$} & \multicolumn{2}{|c|}{$\begin{array}{c}\text { Wage Gap } \\
\text { Estimate }\end{array}$} & \multicolumn{2}{|c|}{ Gap Difference } \\
\hline & & & & & & Public & All & Unadjusted & Adjusted \\
\hline 1 & Freeman \& Leonard (1985) & CPS & 1973 & All & All & .12 & .17 & .05 & .05 \\
\hline 2 & & CPS & 1983 & All & All & .08 & .15 & .07 & .07 \\
\hline 3 & & CPS & 1984 & All & All & .11 & .18 & .07 & .07 \\
\hline 4 & Johnson \& Solon (1984) & CPS & 1978 & All & All & .13 & .20 & .07 & .07 \\
\hline 5 & Smith $(1976,1977 a)$ & CPS & 1973 & All & All & $.10 / .12$ & $.21 / .22$ & $.10 / .11$ & $.10 / .11$ \\
\hline 6 & Smith (1977b) & CPS & 1975 & All & All & $.09 / .11$ & $.19 / .19$ & $.08 / .10$ & $.08 / .10$ \\
\hline 7 & Ashenfelter (1978) & CPS & 1973 & $\mathrm{BC}$ & All & .18 & .22 & .04 & .01 \\
\hline 8 & & CPS & 1975 & $\mathrm{BC}$ & All & .18 & .23 & .05 & .02 \\
\hline 9 & Hirsch \& Rufolo (1982) & NLS & 1971 & M 50-64 & All & -.04 & .09 & .13 & .08 \\
\hline 10 & Johnson (1983) & CPS & $1973-76$ & 34 SMSAs & All & .09 & .11 & .02 & .02 \\
\hline 11 & Shapiro (1978) & NLS & 1971 & M $50-64$ & All & .03 & .12 & .09 & .06 \\
\hline 12 & Antos (1983) & CPS & 1979 & WC & Pub & $.09 / .12$ & $.05 / .07$ & $-.05 /-.04$ & $-.02 /-.01$ \\
\hline 13 & Antos $(1980)$ & CPS & 1976 & All & Pub & .19 & .19 & .00 & .00 \\
\hline 14 & Asher \& Popkin (1984) & CPS & 1979 & All & Pub & .07 & .09 & .02 & .02 \\
\hline 15 & Holzer (1982) & CPS & 1978 & M 16-64 & Pub & .11 & .14 & .03 & .00 \\
\hline 16 & Mellow (1983) & CPS & 1978 & All & Pub & .18 & .19 & .01 & .01 \\
\hline 17 & & CPS & 1979 & All & Pub & $.10 / .12$ & $.08 / .10$ & $-.02 /-.02$ & $-.02 /-.02$ \\
\hline 18 & Perloff \& Wachter (1984) & CPS & 1978 & All & Pub & .12 & .16 & .04 & .04 \\
\hline 19 & Hamermesh (1975) & SCF & 1968 & WM HH & GME & .06 & .15 & .09 & .07 \\
\hline 20 & Kalachek \& Raines (1976) & NLS & 1969 & M 48-62 & Gov & .04 & .10 & .15 & .10 \\
\hline 21 & Mincer (1983) & PSID & $1968-78$ & WM & GE & .14 & .13 & -.01 & -.03 \\
\hline 22 & Moore (1980) & PSID & 1970 & FT HH & $\mathrm{GE}$ & .23 & .19 & -.04 & -.05 \\
\hline
\end{tabular}




\begin{tabular}{|c|c|c|c|c|c|c|c|c|c|}
\hline 23 & Moore \& Raisian (1981) & PSID & $1967-77$ & $\mathbf{M ~ H H}$ & GE & .11 & .21 & .09 & .05 \\
\hline 24 & Moore \& Raisian (1982, 1983) & PSID & 1967 & M HH & Gov & .17 & .22 & .05 & .01 \\
\hline 25 & & PSID & 1968 & М $\mathrm{HH}$ & Gov & .10 & .21 & .11 & .07 \\
\hline 26 & & PSID & 1969 & М $\mathbf{H H}$ & Gov & .06 & .18 & .12 & .08 \\
\hline 27 & & PSID & 1970 & М $\mathbf{H H}$ & Gov & .11 & .19 & .08 & .04 \\
\hline 28 & & PSID & 1971 & М $\mathbf{H H}$ & Gov & .05 & .23 & .18 & .14 \\
\hline 29 & & PSID & 1972 & $\mathbf{M ~} \mathbf{H H}$ & Gov & .00 & .19 & .19 & .15 \\
\hline 30 & & PSID & 1973 & $\mathbf{M ~ H H}$ & Gov & .16 & .21 & .05 & .01 \\
\hline 31 & & PSID & 1974 & М $\mathbf{H H}$ & Gov & .14 & .21 & .07 & .03 \\
\hline 32 & & PSID & 1975 & М $\mathbf{H H}$ & Gov & .17 & .23 & .06 & .02 \\
\hline 33 & & PSID & 1976 & $\mathbf{M} \mathbf{H H}$ & Gov & .15 & .25 & .10 & .06 \\
\hline 34 & & PSID & 1977 & М $\mathbf{H H}$ & Gov & .12 & .23 & .11 & .07 \\
\hline 35 & & PSID & $1967-77$ & М $\mathbf{H H}$ & Gov & .11 & .21 & .10 & .06 \\
\hline
\end{tabular}

Notes:

Column 3: Lines 1-8, 10, 12-18: data source is Current Population Survey.

Lines 9, 11, 20: data source is National Longitudinal Survey.

Line 19: data source is Survey of Consumer Finances.

Lines 21-35: data source is Panel Study of Income Dynamics.

Column 5: BC

BC = blue-collar

M $\quad$ = male

WM $=$ white male

HH = household head

$\mathrm{MHH}=$ male, household head

WM HH = white male, household head

FT HH = full-time, household head

M 50-64 = male, $50-64$ years old

M 16-64 = male, $16-64$ years old

M 48-62 = male, $48-62$ years old

SMSA $=$ Standard Metropolitan Statistical Area

Column 6: Pub = public administration industry

Gov = government industry

$\mathrm{GE}=$ government industry and educational services industry

GME = government industry, medical services industry and educational services industry 
administration industry in the Current Population Survey (CPS) industry classification. The public sector and matching all-sector wage gap estimates that I have retrieved from these twenty-two studies are summarized in columns 7 and 8 , while the differences in the gap estimates between the public sector and the all-sector are given in columns 9 and 10 .

The table presents the studies in four groupings. Lines 1-6 are studies in which the coverage of wage and salary workers has few major exclusions and gap estimates are available for the whole of the public sector as well as the private sector. In this respect these studies provide the most complete picture of recent differences between the public and private sector in the union/nonunion wage gap. Lines 7-11 give wage gap estimates for the public sector that pertain to the whole of that sector but where the coverage of wage and salary workers is incomplete: Ashenfelter (1978), blue-collar workers; Hirsch and Rufolo (1982) and Shapiro (1978), males 50-64 years of age; and Hirsch and Rufolo (1982), workers in large standard metropolitan areas. The six studies on lines 12-18 pertain only to public administration, which covers about one-third of the whole public sector. In addition, Antos (1983) on line 12 covers only white-collar workers and Holzer (1982) on line 15 only male workers. The seven studies listed on lines 19-35 have wage gap estimates that pertain to less than the whole of the public sector and the coverage of wage and salary workers is incomplete: Hamermesh (1975) and Mincer (1983), white males; Kalachek and Raines (1976), and Moore and Raisian (1981; 1982; 1983), males; and Moore (1980), full-time household heads.

I turn now to the central question of this paper: Is the mean wage gap in the public sector as large or larger than that in all sectors of the economy? To answer this, turn to the estimates in columns 9 and 10 of the all-sector minus public sector gap differences for the broadest coverage of wage and salary workers and of public sector workers. The adjusted gap differences in column 10 incorporate the following adjustments to those in column 9 for exclusions of worker coverage and for overweighting of black workers. (See section 6.3 below for a discussion of wage gaps for the different groups that underlie these adjustments):

1. Overweighting of blacks: NLS data: subtract 0.02 (lines 9 and 20) PSID data: subtract 0.01 (lines 22-35)

2. Exclusion of white-collar workers: Subtract 0.03 (lines 7 and 8)

3. Exclusion of blue-collar workers: Add 0.03 (line 12)

4. Exclusion of females: Subtract 0.03 (lines 9, 11, 15, 19-21, 23-35)

5. Exclusion of black males: Add 0.01 (lines 19 and 20)

I have too little information to adjust lines 9,11 , and 20 for their age 
exclusions; lines 9 and 10 for excluding workers outside of large SMSA's; lines 19 and $22-35$ for excluding those who are not household heads; and line 22 for the restriction to full-time workers.

The adjusted gap differences in column 10 range from -0.05 to 0.15 and show little or no trend. Therefore, in judging the magnitude of the mean gap difference I will ignore date differences. The mean of the column 10 figures (using midpoints of estimate ranges) on lines 1-35 is 0.044 and the standard deviation is 0.045 . (This mean, 0.044 , gives disproportional weight to authorships providing estimates for more than one date. When figures are first averaged within each authorship and each authorship is represented by this average, the mean is 0.033 .)

The best of the estimates in terms of worker and public sector coverage are those on lines 1-6. The adjusted gap differences on these lines average 0.077 (counting each authorship once). Next best in this respect are those on lines $7-11$ which average 0.044 . (The corresponding average of the unadjusted figures, however, is 0.071.)

The all-sector minus public sector gap differences on lines 12-35 may be seriously flawed, in my judgment, by incomplete coverage of the public sector. As I mentioned, on lines 12-18 the gap estimates for the public sector pertain only to the public administration industry which employs only about one-third of the public sector work force. The column 10 figures on lines $12-18$ average 0.008 . Similarly, the public sector wage gap estimates on lines 19-35 all cover the government industry which I presume is mainly public administration. Those on lines 19 and 21-23 also cover educational services, and on line 19 medical services are included. I strongly suspect that both the educational services and medical services industries include private as well as public workers. The mean of the column 10 figures on lines 19-35 is 0.029 (counting each authorship only once). The corresponding mean of the unadjusted figures in column 9 is 0.057 . Thus, on the basis of the adjusted estimates in column 10 of Table 6.1, I put the excess of the mean wage gap in all sectors over that in the public sector in the range 0.04 to 0.08 . This gives rather greater weight to lines $1-11$ than to lines $12-35$.

Six studies in table 6.1 (namely, Smith [1976, 1977a, 1977b] on lines 5 and 6; Asher and Popkin [1984] on line 14; and Perloff and Wachter [1984] on line 20) and one study not covered in the table (Freeman, 1984) reported public sector wage gap estimates by level of government-federal, state, and local. (In Kalachek and Raines [1976], state and local were combined.) All of the studies showed that the wage gap for the federal government was below the average gap for all levels of government. The five studies that reported separate estimates for local governments all placed the wage gap for local governments above the average for all levels of government. Estimates drawn from these five 
studies of the excess of the mean gap for local governments over that for all government levels are shown below.

\section{Study}

Smith $(1976 ; 1977 a)$

Smith (1977b)

Asher and Popkin (1984)

Perloff and Wachter (1984)

Freeman (1984)

Freeman (1984)
Year

1973

1975

1979

1978

1973

1981
Coverage

All

All

Public Admin.

Public Admin.

Public Admin.

Public Admin.
Excess

$.00 / .02$

$.02 / .03$

.04

.06

.05

.02

These estimates average 0.03 to 0.04 . They suggest that the adjusted mean wage gap for local government workers was in the range 0.10 to 0.15 in 1967-79. Thus I cannot rule out the possibility that the mean union/nonunion wage gap for the local government sector was as great as that for all U.S. wage and salary workers.

\subsection{Differences in Union/Nonunion Wage Gaps by Worker and Employment Characteristics}

I turn next to the question: Does the union/nonunion wage gap vary in the same way in the public sector as in the private sector with respect to such worker and employment characteristics as sex, race, and occupation? Eight of the studies in table 6.1 provide information on the wage gap difference by sex (male minus female). Table 6.2 is a tabulation of this information. For white-collar workers (line 4), clerks (line 11), and salaried workers in SMSA's (line 23) the estimated male minus female gap difference on the average is negative and of about the same numerical size in both the public and private sectors. In contrast, for blue-collar workers (lines 5, 19, and 20) and hourly-rated workers (line 22) this gap difference on the average is positive in the private sector, negative in the public sector, and the between-sector difference is substantial. For both white- and blue-collar workers taken together (lines $1-3,6,7,15,21$, and 24) the male minus female gap difference in the public sector ranges from -0.10 to -0.01 and averages about -0.05 , while for all-sectors the range is -0.01 to 0.03 and the average is about 0.01 . Thus Table 6.2 provides substantial evidence that the gap difference by sex varies considerably with collar color and sector (public vs. private). There is also a somewhat weak suggestion in the table that the gap difference by sex varies with the "level" of government within the public sector.

Consider now the estimates of the wage gap difference by race (white minus black) summarized in table 6.3. In Lewis (1986, 119-25), I observed that the estimates of the white minus black gap difference (for 


\begin{tabular}{|c|c|c|c|c|c|c|}
\hline \multirow{3}{*}{$\begin{array}{l}\text { (1) } \\
\text { Line } \\
\text { No. }\end{array}$} & \multirow[t]{2}{*}{ (2) } & \multirow[t]{2}{*}{ (3) } & \multirow[t]{2}{*}{ (4) } & \multirow[t]{2}{*}{ (5) } & (6) & (7) \\
\hline & & & & & \multicolumn{2}{|c|}{ Gap Difference } \\
\hline & Study & Year & $\begin{array}{l}\text { worker } \\
\text { Coverage }\end{array}$ & Sector & Public & All \\
\hline 1 & Freeman \& Leonard (1985) & 1973 & All & All & -.01 & .02 \\
\hline 2 & & 1983 & All & All & -.03 & .03 \\
\hline 3 & & 1984 & All & All & -.04 & .00 \\
\hline 4 & & 1984 & White-collar & All & -.07 & -.06 \\
\hline 5 & & 1984 & Blue-collar & All & -.04 & .02 \\
\hline 6 & Johnson \& Solon (1984) & 1978 & All & All & -.04 & .02 \\
\hline 7 & Smith $(1976,1977 a)$ & 1973 & All & All & -.02 & .03 \\
\hline 8 & & 1973 & All & Federal & $-.07 /-.03$ & .03 \\
\hline 9 & & 1973 & All & State & $.00 / .04$ & .03 \\
\hline 10 & & 1973 & All & Local & $-.03 / .01$ & .03 \\
\hline 11 & Smith (1976) & 1973 & Clerks & All & -.02 & -.04 \\
\hline 12 & & 1973 & Clerks & Federal & $.00 / .01$ & -.04 \\
\hline 13 & & 1973 & Clerks & State & .22 & -.04 \\
\hline 14 & & 1973 & Clerks & Local & -.05 & -.04 \\
\hline 15 & Smith (1977b) & 1975 & All & All & $-.08 /-.06$ & $-.01 / .00$ \\
\hline 16 & & 1975 & All & Federal & $-.17 /-.11$ & $-.01 / .00$ \\
\hline 17 & & 1975 & All & State & $-.13 /-.09$ & $-.01 / .00$ \\
\hline 18 & & 1975 & All & Local & $-.03 / .00$ & $-.01 / .00$ \\
\hline 19 & Ashenfelter (1978) & 1973 & Blue-collar & All & .05 & .06 \\
\hline 20 & & 1975 & Blue-collar & All & -.13 & .04 \\
\hline 21 & Johnson (1983) & $1973-76$ & SMSA's & All & -.07 & .00 \\
\hline 22 & & $1973-76$ & SMSA's, hourly & All & -.13 & .01 \\
\hline 23 & & $1973-76$ & SMSA's, salaried & All & -.03 & -.01 \\
\hline 24 & Antos et.al. (1980) & 1976 & All & Pubad & -.10 & .00 \\
\hline
\end{tabular}

Notes: Column 4: SMSA = Standard Metropolitan Statistical Area.

Column 5: Pubad = public administration industry.

Line 8: The range in column 6 covers three estimates.

Lines 9, 10,12,15-19: The ranges in columns 6 and 7 cover two estimates. 


\begin{tabular}{|c|c|c|c|c|c|c|}
\hline \multirow{2}{*}{$\begin{array}{l}\text { (1) } \\
\text { Line } \\
\text { No. }\end{array}$} & \multirow{2}{*}{$\begin{array}{c}\text { (2) } \\
\text { Study }\end{array}$} & \multirow{2}{*}{$\begin{array}{l}\text { (3) } \\
\text { Year }\end{array}$} & \multirow[b]{2}{*}{ Worker Coverage } & \multirow{2}{*}{$\begin{array}{c}\text { (5) } \\
\text { Public } \\
\text { Sector }\end{array}$} & \multicolumn{2}{|c|}{$\begin{array}{c}(6) \quad(7) \\
\text { Gap Difference }\end{array}$} \\
\hline & & & & & Public & All \\
\hline 1 & Ashenfelter (1978) & 1973 & $\mathrm{BC}$ & All & -.12 & .01 \\
\hline 2 & & 1973 & Male BC & All & -.11 & -.01 \\
\hline 3 & & 1973 & Male craftsmen & All & -.16 & .04 \\
\hline 4 & & 1973 & Male operatives & All & -.10 & -.06 \\
\hline 5 & & 1973 & Male laborers & All & -.09 & .06 \\
\hline 6 & & 1975 & $\mathrm{BC}$ & All & -.02 & -.01 \\
\hline 7 & & 1975 & Male BC & All & -.01 & -.02 \\
\hline 8 & & 1975 & Male craftsmen & All & .01 & .02 \\
\hline 9 & & 1975 & Male operatives & All & -.05 & -.03 \\
\hline 10 & & 1975 & Male laborers & All & .02 & -.01 \\
\hline 11 & Shapiro (1978) & 1971 & Male, 50-64 & All & -.05 & -.15 \\
\hline 12 & & 1971 & Male, $50-64, \mathrm{BC}$ & All & .10 & -.04 \\
\hline 13 & & 1971 & Male, 50-64, WC & All & -.18 & -.29 \\
\hline 14 & Moore \& Raisian $(1982 ; 1983)$ & $1967-77$ & Male $\mathbf{H H}$ & Gov & -.05 & -.09 \\
\hline 15 & Moore \& Raisian (1981) & $1967-77$ & Male $\mathrm{HH}$ & Gov \& Ed & -.02 & -.08 \\
\hline 16 & & $1967-77$ & Male $\mathrm{HH}$ & Ed & -.05 & -.08 \\
\hline 17 & & $1967-77$ & Male $\mathrm{HH}$ & Gov & .02 & -.08 \\
\hline
\end{tabular}

Notes: Column 4: $\mathrm{BC}=$ blue-collar, $\mathrm{WC}=$ white-collar, $\mathrm{HH}=$ household head.

Column 5: Gov = government industry, Ed = educational services industry.

Lines 1-10: data source is Current Population Survey.

Lines 11-13: data source is National Longitudinal Survey.

Lines 14-17: data source is Panel Study of Income Dynamics. 
all sectors) tended to differ substantially by data source. According to the CPS data the estimated mean difference was close to zero, while other data sources pointed to a mean gap difference of -0.05 to -0.10 . The white minus black gap difference estimates in Table 6.3 also differ by data source. The estimates on lines 1-10 come from CPS data. The all-sector figures on lines 1 and 2 (for 1973) and lines 6 and 7 (1975) are close to zero. The corresponding figures for the public sector for 1973, however, are -0.12 and -0.11 , but those for 1975 are close to zero.

The estimates on lines 11-17, based on other sources of data and only for males tell a rather different story. For all sectors the white minus black gap difference estimates on lines 11, 14, and 15 average about -0.11 in all sectors and about -0.04 in the public sector. That is, the estimated black wage gap exceeds that for whites by considerably less in the public than in the private sector, according to data from the NLS and the PSID.

I turn now to wage gap differences by collar-color (white-collar minus blue-collar). Table 6.4 summarizes the pertinent estimates. I have included Holzer's study (1982) though the gap differences in this study are for salaried vs. hourly-rated workers. First note that all of the figures in columns 6 and 7 are negative. In both the public and private sectors the estimated white-collar wage gap is smaller than that for blue-collar workers, for both males and females, blacks and whites. Furthermore, the excess of the blue-collar gap over the white-collar gap in the public sector is less than or equal to that in all sectors except on lines 7-9 from Shapiro's study (1978). Indeed, the figures for that study are clearly outliers and in what follows I ignore them.

Freeman and Leonard (1985) and Johnson (1983) agree that for females the occupational gap difference is about the same in the public and private sectors, but for male workers the blue-collar minus whitecollar gap difference is smaller in the public than in the private sector. On lines $2,5,10,13,14,16$, and 18, all pertaining to male workers, the figures in column 6 for the public sector range from -0.15 to -0.02 and average about -0.08 , while those in column 7 for all sectors range from -0.25 to -0.15 and average about -0.22 or about 0.14 larger numerically than in the public sector. Thus there is some evidence that at least for males, the blue-collar minus white-collar gap difference is substantially larger in the private than in the public sector.

In addition to analyzing union/nonunion wage gaps by sex, race, and collar-color, I have also examined estimates of gaps for several detailed occupations, including fire fighters, police, hospital workers, and teachers. My conclusions from this analysis (presented in the longer conference paper from which this chapter is drawn) can be summarized briefly: 


\begin{tabular}{|c|c|c|c|c|c|c|}
\hline \multirow{3}{*}{$\begin{array}{l}(1) \\
\text { Line } \\
\text { No. }\end{array}$} & \multirow{3}{*}{$\begin{array}{c}\text { (2) } \\
\text { Study }\end{array}$} & \multirow{3}{*}{$\begin{array}{l}(3) \\
\text { Year }\end{array}$} & \multirow[b]{3}{*}{ Worker Coverage } & \multirow{3}{*}{$\begin{array}{c}(5) \\
\text { Public } \\
\text { Sector }\end{array}$} & \multirow{2}{*}{\multicolumn{2}{|c|}{$\begin{array}{c}\text { (6) } \\
\text { Gap Difference }\end{array}$}} \\
\hline & & & & & & \\
\hline & & & & & Public & All \\
\hline 1 & Freeman \& Leonard (1985) & 1984 & All & All & -.07 & -.10 \\
\hline 2 & & 1984 & Male & All & -.10 & -.15 \\
\hline 3 & & 1984 & Female & All & -.07 & -.07 \\
\hline 4 & Johnson (1983) & $1973-76$ & SMSA's & All & -.08 & -.16 \\
\hline 5 & & $1973-76$ & SMSA's, male & All & -.04 & -.16 \\
\hline 6 & & $1973-76$ & SMSA's, female & All & -.14 & -.14 \\
\hline 7 & Shapiro (1978) & 1971 & Male, 50-64 & All & -.39 & -.35 \\
\hline 8 & & 1971 & M 50-64, white & All & -.42 & -.35 \\
\hline 9 & & 1971 & M 50-64, black & All & -.14 & -.10 \\
\hline 10 & Holzer (1982) & 1978 & Male, $16-64$ & Pubad & -.02 & -.22 \\
\hline 11 & & 1978 & Male, 16-24 & Pubad & -.06 & -.16 \\
\hline 12 & & 1978 & Male, 25-64 & Pubad & -.01 & -.20 \\
\hline 13 & Moore \& Raisian $(1982 ; 1983)$ & $1967-77$ & Male $\mathrm{HH}$ & Gov & -.15 & -.23 \\
\hline 14 & Moore \& Raisian (1981) & $1967-77$ & Male HH & Gov \& Ed & -.10 & -.25 \\
\hline 15 & & $1967-77$ & Male $\mathrm{HH}$, white & Gov \& Ed & -.09 & -.23 \\
\hline 16 & & $1967-77$ & Male $\mathrm{HH}$ & Ed & -.09 & -.25 \\
\hline 17 & & $1967-77$ & Male $\mathrm{HH}$, white & Ed & -.03 & -.23 \\
\hline 18 & & $1967-77$ & Male $\mathrm{HH}$ & Gov & -.09 & -.25 \\
\hline 19 & & $1967-77$ & Male $\mathrm{HH}$, white & Gov & -.12 & -.23 \\
\hline
\end{tabular}

Notes: Column 4: SMSA = Standard Metropolitan Statistical Area, M 50-64 = males 50-64 years old, $\mathrm{HH}=$ household head.

Column 5: Pubad = public administration industry, Gov = government industry, Ed = educational services industry.

Lines 4-6: Gap differences in columns 6 and 7 are salaried minus hourly rated. 
1. Studies of fire fighters indicate that in the decade 1966-76, the union/nonunion wage gap may have trended upward, but even in 1976 it was probably below the corresponding average gap for all U.S. wage and salary workers. For police, wage gap estimates drawn from nine studies put the mean gap throughout the decade 1971-81 at roughly .05 below the all-worker gap. But are fire fighters and police officers really average U.S. workers? In particular, if the more apt comparison is with blue-collar rather than white-collar workers, the mean wage gaps for both police and fire fighters are even lower, relative to the more apt comparison group, than the above figures put it.

2. For public sector hospital workers, I estimate that the mean gap is about two-thirds as large as the corresponding mean for all U.S. wage and salary workers in the same period. However, the publicsector mean wage gaps for LPN's, technicians, and nonprofessionals exceeded their private sector counterparts.

3. For teachers, wage gap estimates drawn from nineteen studies indicate that until the middle 1970's, the mean gap for teachers was below that for all U.S. wage and salary workers, by about 0.05 . In terms of work force mix, however, comparing the average teacher to the average U.S. wage and salary worker is misleading. Teachers are skilled white-collar workers. In Lewis (1986, 128 and 164) I estimated that the mean wage gap for all white-collar workers was about 0.05 below that for all workers. Thus even before 1976 the mean wage gap for teachers may have been roughly as high as that for private sector white-collar workers.

\subsection{Conclusion}

In terms of worker coverage in the public sector, the best of the public sector gap estimates are those drawn from the twenty-two studies covered in table 6.1. These studies indicate that the mean wage gap (after adjustments for fringes and work force mix) in the public sector in 1973-84 moved approximately parallel to that in all sectors, but at a level lower by about 0.03 to 0.07 . I estimate that the public sector gap in this period averaged about 0.08 to 0.12 , which is surely not negligible.

In terms of union/nonunion wage gaps for different groups of workers, there is, I judge, much variation in the union/nonunion wage gap across groups of workers within each of the two sectors, public and private. Furthermore, the variation in the public sector does not parallel in all of its detail that in the private sector. Thus, though the public sector gaps are typically somewhat below their private sector 
counterparts, there are important exceptions to this difference especially among employees of local governments: public school teachers, clerical workers, refuse collectors, local transit bus drivers, licensed practical nurses, hospital technicians, nonprofessional hospital workers, and undoubtedly some others.

\section{Notes}

1. For reasons explained in Lewis (1986), I believe that neither simultaneous equations nor panel data estimates of union wage effects are sufficiently reliable to be included in a survey of this type.

2. There have been several earlier surveys of public sector wage gap estimates: Lewin 1977; Lewin, Horton, and Kuhn 1979; Honadle 1981; Mitchell 1983; Ehrenberg and Schwarz 1983; and Freeman 1984. None of the first four of these surveys covered as many as twenty public sector wage gap studies. Ehrenberg and Schwarz covered thirty-five such studies and Freeman forty. The six surveys taken together cited public sector wage gap estimates drawn from fifty studies. For reasons stated in section 6.1, I have ignored seventeen of these fifty studies while adding forty-two studies that I presume were not covered in these earlier surveys either because of their newness or because their public sector wage gap estimates were well hidden.

The general tenor of the conclusions drawn by the authors of these six studies from the wage gap estimates surveyed was that the average wage gap in the public sector, though positive, was smaller than that in the private sector. For example, Ehrenberg and Schwarz $(1983,10)$ commented that: "The estimated relative wage differentials associated with union membership or collective bargaining coverage are typically smaller than 10 percent and rarely exceed 20 percent. These estimates are considerably lower than the estimates obtained from private sector studies and they suggest that the relative wage effects of unions have been less in the public sector than the private sector." And Freeman (1984, 31-33), referring to the public sector, stated that: "In the absence of a comprehensive study of various data sets, definitions of government employees, and different models, the safest conclusions are that the union effects differ significantly over time and are generally smaller than those in the private sector (for any of the reasons given earlier) but are far from negligible."

3 . In the longer conference paper from which this is taken I consider several estimation problems that I do not deal with in this chapter. These include fringe benefit costs omitted from most studies, public sector hours gaps, and the skill mix of work forces. Detailed consideration of these problems shows that their resolution does not substantively affect the results given here.

4. Pages 183 and 185 of Lewis (1986) provide some support for this view.

5 . Of course, a worker may be covered by a contract and not be a member of the covering union, but there are relatively so few covered nonmembers, except among young workers, that it makes little differences in wage gap estimates whether the union status dichotomy is for contract coverage or union membership. For evidence see Lewis (1986, 109-11).

6. In Lewis (1986, 16-18) I discuss several studies that I read as claiming to estimate wage gains $\bar{A}_{n}$ from the same cross-sectional wage equations that 
were used to estimate wage gaps $\bar{M}$. In these studies the fitted wage equations were of the form:

$$
\begin{aligned}
\hat{W}=a_{n}+\Sigma a_{n i} X_{i}+ & \Sigma b_{n j} y_{j}+U\left[\left(a_{u}-a_{n}\right)+\Sigma\left(a_{u i}-a_{n i}\right) X_{i}\right. \\
& \left.+\Sigma\left(b_{u j}-b_{n j}\right) y_{j}\right],
\end{aligned}
$$

where $\hat{W}$ is the estimated value of $W$ and the $y$ variables are extent of unionism (fraction unionized) variables by industry and/or occupation and/or locality, etc. I interpret these studies as implicitly estimating $\hat{V}$ by setting $U$ and the $y$ 's equal to zero in the equation for $\hat{W}$ above, so that:

$$
\hat{V}=a_{n}+\Sigma a_{n i} X_{i} ; \hat{A}_{n}=\Sigma b_{n j} y_{j} \text {. }
$$

This procedure assumes that, conditional on the control variable $X$ 's, all workers in the hypothetical economy would be paid a wage $V$ equal to the wage $W$ that is paid in the actual economy to nonunion workers $(U=0)$ in nonunion sectors $(y$ 's $=0$ ). I know of no compelling analytical reasons or convincing empirical evidence supporting this assumption. Furthermore, in Lewis (1986, 38-44, 147-53), I present evidence that the estimated coefficients $b_{n j}$ on the $y$ variables in the above equations for $W$ and $A$ are quite sensitive to the choices of the set of $y$ variables, the specification of the control $X$ 's, and the worker coverage in the $W$ equation. I am not arguing that $A_{n}$ cannot be estimated; however, I know of no estimates of $A_{n}$ that command widespread confidence among students of U.S. unionism.

\section{References}

Adamache, Killard W., and Frank A. Sloan. 1982. Unions and hospitals: Some unresolved issues. Journal of Health Economics 1:81-108.

Antos, Joseph R. 1983. Union effects on white-collar compensation. Industrial and Labor Relations Review 36:461-79.

Antos, Joseph R., Mark Chandler, and Wesley Mellow. 1980. Sex differences in union membership. Industrial and Labor Relations Review 33:162-69.

Ashenfelter, Orley. 1971. The effect of unionization on wages in the public sector: The case of fire fighters. Industrial and Labor Relations Review 24:191-202.

1978. Union relative wage effects: New evidence and a survey of their implications for wage inflation. In Econometric contributions to public policy, ed. R. Stone and W. Peterson. New York: St. Martins Press.

Asher, Martin, and Joel Popkin. 1984. The effect of gender and race differentials on public-private wage comparisons: A study of postal workers. Industrial and Labor Relations Review 38:16-25.

Baird, Robert N., and John H. Landon. 1972. The effects of collective bargaining on public school teachers' salaries: Comment. Industrial and Labor Relations Review 25:410-17.

Balkin, David B. 1984. The effect of unions on the compensation of secretaries in municipal government. Journal of Collective Negotiations in the Public Sector 13:29-37.

Bartel, Ann, and David Lewin. 1981. Wages and unionism in the public sector: The case of police. Review of Economics and Statistics 63:53-59. 
Baugh, William H., and Joe A. Stone. 1982. Teachers, unions, and wages in the 1970s: Unionism now pays. Industrial and Labor Relations Review 35:36876.

Becker, Brian E. 1979. Union impact on wages and fringe benefits of hospital nonprofessionals. Quarterly Review of Economics and Business 19:27-44.

Cain, Glen G., Brian E. Becker, Catherine G. McLaughlin, and Albert E. Schwenk. 1981. The effect of unions on wages in hospitals. Research in Labor Economics 4:191-320.

Chambers, Jay G. 1977. The impact of collective bargaining for teachers on resource allocation in public school districts. Journal of Urban Economics 4:324-39.

1981. The impact of bargaining and bargaining statutes on the earnings of public school teachers: A comparison in California and Missouri. Economics of Education Review 1:467-81.

Cole, Raymond E. 1977. Some salary effects on Arkansas teachers of professional negotiations occurring in the absence of statutory sanctions. Journal of Collective Negotiations in the Public Sector 6:63-72.

Delaney, John Thomas, and Peter Feuille. 1983. Bargaining, arbitration, and public wages. In Proceedings of the thirty-fifth annual meeting. Madison: Industrial Relations Research Association.

Edwards, Linda N., and Franklin R. Edwards. 1982a. Wellington-Winter revisited: The case of municipal sanitation collection. Industrial and Labor Relations Review 35:307-17.

$1982 \mathrm{~b}$. Public unions, local government structure and the compensation of municipal sanitation workers. Economic Inquiry 20:405-25.

Ehrenberg, Ronald G. 1973. Municipal government structure, unionization, and the wages of fire fighters. Industrial and Labor Relations Review 27:3648.

1980. Retirement system characteristics and compensating wage differentials in the public sector. Industrial and Labor Relations Review 33:47083.

Ehrenberg, Ronald G., and Joshua L. Schwarz. 1983. Public sector labor markets. NBER Working Paper no. 1179. Cambridge, Mass.: National Bureau of Economic Research.

Ehrenberg, Ronald G., Daniel R. Sherman, and Joshua L. Schwarz. 1983. Unions and productivity in the public sector: A study of municipal libraries. Industrial and Labor Relations Review 36:199-213.

Feldman, Roger, Lung-Fei Lee, and Richard Hoffbeck. 1980. Hospital employees' wages and labor union organization. Final report, grant no. 1-R03HS03649-01, National Center for Health Services Research (November).

1981. An empirical study of irreversible choices: Unionism and wages revisited. Mimeo (November). Minneapolis: University of Minnesota.

Feldman, Roger, and Richard Scheffler. 1982. Union impact on hospital wages and fringe benefits. Industrial and Labor Relations Review 35:196-206.

Feuille, Peter, and John Thomas Delaney. 1986. Collective bargaining, interest arbitration, and police salaries. Industrial and Labor Relations Review 39:22840.

Feuille, Peter, Wallace Hendricks, and John Thomas Delaney. 1983. The impact of collective bargaining and interest arbitration on policing. Final report, grant no. 81-IJ-CX-0074, National Institute of Justice, U.S. Department of Justice (December). 
1985. Police bargaining, arbitration, and fringe benefits. Journal of Labor Research 6:1-20.

Freeman, Richard B. 1984. Unionism comes to the public sector. NBER Working Paper no. 1452. Cambridge, Mass.: National Bureau of Economic Research.

Freeman, Richard B., C. Ichniowski, and H. Lauer. 1985. Collective bargaining laws and threat effects of unionism in the determination of police compensation. NBER Working Paper no. 1578. Cambridge, Mass.: National Bureau of Economic Research.

Freeman, Richard B., and J. Leonard. 1985. Union maids: Unions and the female workforce. NBER Working Paper no. 1652. Cambridge, Mass.: National Bureau of Economic Research.

Frey, Donald E. 1975. Wage determination in public schools and the effects of unionization. In Labor in the public and nonprofit sectors, ed. Daniel S. Hamermesh. Princeton: Princeton University Press.

Gallagher, Daniel G. 1978. De facto bargaining and teacher salary levels: The Illinois experience. Journal of Collective Negotiations in the Public Sector $7: 243-54$.

Gomez-Mejia, Luis R., and David B. Balkin. 1984. Union impacts on secretarial earnings: A public sector case. Industrial Relations 23:97-102.

Gustman, Alan L., and M. O. Clement. 1977. Teachers' salary differentials and equality of educational opportunity. Industrial and Labor Relations Review $31: 61-70$.

Gustman, Alan L., and Martin Segal. 1976. The impact of teachers' unions. Final report, project no. 4-0136, National Institute of Education (September).

Hall, W. Clayton, and Norman E. Carroll. 1973. The effect of teachers' organizations on salaries and class size. Industrial and Labor Relations Review 26:834-41.

Hall, W. Clayton, and Bruce Vanderporten. 1977. Unionization, monopsony power, and police salaries, Industrial Relations 16:94-100.

Hamermesh, Daniel S. 1975. The effects of government ownership on union wages. In Labor in the public and nonprofit sectors, ed. Daniel S. Hamermesh. Princeton: Princeton University Press.

Hirsch, Werner Z., and Anthony M. Rufolo. 1982. Determinants of municipal wages: Some tests of the competitive wage hypothesis. Research in Urban Economics 2:309-27.

Holmes, Alexander B. 1976. Effects of union activity on teacher earnings. Industrial Relations 15:328-32.

1979. Union activity and teacher salary structures. Industrial Relations 18:79-85.

Holzer, Harry J. 1982. Unions and the labor market status of white and minority youth. Industrial and Labor Relations Review 35:392-405.

Honadle, Beth Walter. 1981. Wage determination in the public sector: A critical review of the literature. Journal of Collective Negotiations in the Public Sector 10:309-25.

Ichniowski, Casey. 1980. Economic effects of the firefighters' union. Industrial and Labor Relations Review 33:198-211.

Johnson, George E. 1983. Inter-metropolitan wage differentials in the U.S. In The measurement of labor cost, ed. Jack E. Triplett. Chicago: University of Chicago Press.

Johnson, George E., and Gary Solon. 1984. Pay differences between women's 
and men's jobs: The empirical foundations of comparable worth legislation. NBER Working Paper no. 1472. Cambridge, Mass.: National Bureau of Economic Research.

Kalachek, Edward, and Fredric Raines. 1976. The structure of wage differences among mature male workers. Journal of Human Resources 11:484-506.

Lewin, David. 1977. Public sector labor relations. Labor History 18:133-44.

1983. The effects of civil service systems and unionism on pay outcomes in the public sector. Advances in Industrial and Labor Relations $1: 131-61$.

Lewin, David, Raymond D. Horton, and James W. Kuhn. 1979. Collective bargaining and manpower utilization in big city governments. Montclair, $\mathrm{NJ}$ : Allanheld, Osmun and Co.

Lewin, David, and John H. Keith, Jr. 1976. Managerial responses to perceived labor shortages. Criminology 14:65-92.

Lewis, H. Gregg. 1983. Union Relative Wage Effects: A Survey of Macro Estimates," Journal of Labor Economics 1:1-27.

1986. Union relative wage effects: A survey. Chicago: University of Chicago Press.

Link, Charles R., and John H. Landon. 1975. Monopsony and union power in the market for nurses. Southern Economic Journal 41:649-59.

Lipsky, David B., and John E. Drotning. 1973. The influence of collective bargaining on teachers' salaries in New York state. Industrial and Labor Relations Review 27:18-35.

McLaughlin, Catherine G. 1980. The impact of unions on hospital wages. Ph.D. diss., University of Wisconsin, Madison.

Mellow, Wesley. 1983. Employer size, unionism, and wages. Research in Labor Economics Supplement 2:253-82.

Mincer, Jacob. 1983. Union effects: Wages, turnover, and job training. $R e-$ search in Labor Economics Supplement 2:217-52.

Mitchell, Daniel J. B. 1983. Unions and wages in the public sector: A review of recent evidence. Journal of Collective Negotiations in the Public Sector 12:337-53.

Moore, Gary A. 1976. The effect of collective bargaining on internal salary structure in the public schools. Industrial and Labor Relations Review 29:35262.

Moore, William J. 1980. Membership and wage impact of right-to-work laws. Journal of Labor Research 1:349-68.

Moore, William J., and John Raisian. 1981. Unionism and wage rates in the public and private sectors: A comparative time series analysis. Mimeo (October). Washington, D.C.: U.S. Bureau of Labor Statistics.

1982. A times series analysis of union/nonunion relative wage effects in the public sector. In Proceedings of the thirty-fourth annual meeting. Madison: Industrial Relations Research Association.

1983. The level and growth of union/nonunion relative wage effects, 1967-77. Journal of Labor Research 4:65-79.

Noam, Eli M. 1983. The effect of unionization and civil service on the salaries and productivity of regulators. Research in Labor Economics Supplement 2:157-70.

Perloff, Jeffrey M., and Michael L. Wachter. 1984. Wage comparability in the U.S. Postal Service. Industrial and Labor Relations Review 38:26-35.

Schmenner, Roger W. 1973. The determination of municipal employee wages. Review of Economics and Statistics 55:83-90. 
Shapiro, David. 1978. Relative wage effects of unions in the public and private sectors. Industrial and Labor Relations Review 31:193-203.

Sloan, Frank A., and Killard W. Adamache. 1984. The role of unions in hospital cost inflation. Industrial and Labor Relations Review 37:252-62.

Sloan, Frank A., and Richard A. Elnicki. 1978. Professional nurse wage-setting in hospitals. In Equalizing access to nursing services: The geographic dimension, ed. Frank A. Sloan. Washington, D.C.: U.S. Department of Health, Education, and Welfare (publication no. HRA 78-51).

1979. Determinants of professional nurses wages. Research in Health Economics 1:217-54.

Sloan, Frank A., and Bruce Steinwald. 1980. Hospital labor markets. Lexington, MA: Lexington Books.

Smith, Sharon P. 1976. Are postal workers over- or underpaid? Industrial Relations 15:168-76.

1977a. Government wage differentials. Journal of Urban Economics $4: 248-71$.

1977b. Equal pay in the public sector: Fact or fantasy? Princeton Industrial Relations Section, Princeton University.

Thornton, Robert J. 1971. The effects of collective negotiations on teachers' salaries. Quarterly Review of Economics and Business 11:37-46.

1975. Monopsony and teachers' salaries: Some contrary evidence. Industrial and Labor Relations Review 28:574-75.

Victor, Richard B. 1979. Municipal unions and wage patterns. In Proceedings of the thirty-second annual meeting. Madison: Industrial Relations Research Association.

Zax, Jeffrey S. 1985. Labor relations, wages, and nonwage compensation in municipal employment. NBER Working Paper no. 1582. Cambridge, Mass.: National Bureau of Economic Research.

\section{Comment Zvi Griliches}

As always, Gregg Lewis has provided a valuable contribution to the profession by organizing a mass of studies into a coherent whole. I have two comments. First, all the studies Lewis cites (as well as those on private sector union wage effects) measure the union impact in terms of the geometric mean (i.e., in In units). Does it make sense to use geometric means or might arithmetic means be more appropriate? If I believed that arithmetic means were more relevant, the fact that the variance of In earnings in the union sector is smaller than the variance of In earnings in the nonunion sector (Freeman 1980, 1986) implies that the union/nonunion gap would be smaller if arithmetic means were used rather than geometric. Indeed, with a lognormal distribution, the

Zvi Griliches is Paul M. Warburg Professor of Economics at Harvard University and Director of the National Bureau of Economic Research's Program in Productivity and Technical Change. 
In of the arithmetic mean equals the geometric mean plus one-half the variance of In earnings. As it is likely that unions have a bigger impact in reducing dispersion in the private sector, my guess is that, when measured in arithmetic units, the difference between the union/nonunion wage gaps between the sectors will diminish somewhat compared to the results reported by Lewis.

My second comment relates to the interpretation of all these estimates. What are we to make of them? Do we really believe that there is one "gap" to be found, or ought we to concentrate more on the range of gaps? It reminds me of my own earlier work on the return to schooling and the search for "the" estimate of ability bias. It is interesting, but ultimately one convinces oneself that it all depends on the particular set of data and circumstances in the labor market.

What we have here is a valuable array of the results of different studies made as comparable as is possible at the moment. In principle, they should be the input for theorists, who will take them as stylized facts, use them in constructing a model of sectoral wage determination, and try to explain the differences among them as the result of different supply, demand, and technology of union control, bargaining, and political context variables. For laying the groundwork for such future studies, we owe Gregg Lewis a great debt.

\section{References}

Freeman, R. 1980. Unionism and the dispersion of wages. Industrial and Labor Relations Review 34(October):3-23.

1986. Unionism comes to the public sector. Journal of Economic Literature 24(March):4l-86. 